\title{
PLANT GROWTH-PROMOTING MICROBIAL INOCULANT FOR Schizolobium parahyba pv. parahyba ${ }^{1}$
}

Priscila Jane Romano de Oliveira Gonçalves ${ }^{2}$, Admilton Gonçalves Oliveira ${ }^{3}$, Vanessa Fogaça Freitas ${ }^{4}$, Nathaly Andreoli Chiari ${ }^{5}$, Miguel Perez Navarro ${ }^{3}$, Martha Torres Cely ${ }^{6}$, Alex Carneiro Leal ${ }^{7}$ e Galdino Andrade ${ }^{3}$

\begin{abstract}
Schizolobium parahyba pv. amazonicum (Huber ex Ducke) Barneby (paricá) occurs naturally in the Amazon and is significant commercial importance due to its rapid growth and excellent performance on cropping systems. The aim of this paper was to evaluate a microbial inoculants such as arbuscular mycorrhiza fungi (AMF) and Rhizobium sp. that promote plant growth. The inocula was $10 \mathrm{~g}$ of root colonized and spores of Glomus clarum and/or $1 \mathrm{~mL}$ of cell suspension $\left(10^{7} \mathrm{CFU} / \mathrm{mL}\right)$ of Rhizobium sp. and/or $100 \mathrm{~g}$ of chemical fertilizer NPK 20-05-20 per planting hole. The experimental design was complete randomized blocks with five replications and eight treatments $(\mathrm{n}=800)$. Plant height, stem diameter and plant survival were measured. The results were tested for normality and homogeneity of variances and analyzed by ANOVA and Tukey test $(\mathrm{p}<0.05)$. Rhizobium sp and AM fungi showed no effect on plant growth. Environmental factors probably influenced the effectiveness of symbiosis of both microorganisms and plant growth. The chemical fertilizer increased S. parahyba growth. During the first 120 days plants suffered with drought and frost, and at 180 days plants inoculated with microorganism plus chemical fertilizer showed higher survival when compared with control. The results showed that the microbial inoculants used showed an important role on plant survival after high stress conditions, but not in plant growth. Also was concluded that the planting time should be between November to December to avoid the presence of young plants during winter time that is dry and cold.
\end{abstract}

Keywords: Rhizobium sp.; Glomus; Rhizosphere.

\section{INÓCULO DE MICROGANISMOS PROMOTORES DO CRESCIMENTO PARA Schizolobium parahyba var. parahyba}

\begin{abstract}
RESUMO - Schizolobium parahyba var. amazonicum (Huber ex Ducke) Barneby (paricá) ocorre naturalmente na Amazônia e tem grande importância comercial devido ao seu rápido crescimento e excelente performance no sistema de silvicultura extensiva. O objetivo deste trabalho foi avaliar a inoculação de inoculantes microbianos como fungo micorrízico arbuscular (FMA) e Rhizobium sp. que promovem o crescimento da planta. O inóculo foi composto de $10 \mathrm{~g}$ de raízes colonizadas e esporos de Glomus clarum e, ou, $1 \mathrm{~mL}$ da suspensão de células de Rhizobium sp. (107 UFC/mL) e, ou, $100 \mathrm{~g}$ de fertilizante químico NPK 20-05-20 por cova. O desenho experimental foi em bloco completamente ao acaso, com cinco repetições e oito tratamentos $(n=800)$. Foram
\end{abstract}

\footnotetext{
${ }^{1}$ Recebido em 02.08.2013 aceito para publicação em 15.04.2015.

${ }^{2}$ Universidade de São Paulo, Programa de Pós-Graduação em Microbiologia, São Paulo, SP - Brasil. E-mail: < priromano@usp.br>. ${ }^{3}$ Universidade Estadual de Londrina, Departamento de Microbiologia, Londrina, PR - Brasil. E-mail: <admilton@uel.br>, $<$ micromiguel@gmail.com>e< andradeg@uel.br>.

${ }^{4}$ Universidade Estadual de Londrina, Programa de Pós-Graduação em Microbiologia, Londrina, PR - Brasil. E-mail: <vanessaf_Freitas@hotmail.com>.

${ }^{5}$ Universidade Estadual de Londrina, Graduado em Biologia, Londrina, PR - Brasil. E-mail: <nathalyandreoli@hotmail.com>. ${ }^{6}$ Universidade Federal de Mato Grosso, Doutorado em Microbiologia, Cuiabá, MT - Brasil. E-mail:<vivianatorres.cely@hotmail.com>. ${ }^{7}$ Instituto Agronômico do Paraná, Diretoria Técnico Científica, Área Técnica de Fitotecnia, Londrina, PR - Brasil. E-mail: <alex@iapar.br>.
} 
avaliados o comprimento da Planta, o diâmetro do caule e a sobrevivência da planta. Os resultados foram testados quanto à normalidade e homogeneidade da variância e as diferenças significativas, determinadas pela ANOVA e teste de Tukey $(p<0,05)$. A inoculação do Rhizobium sp e G. clarum não tiveram diferenças significativas em relação ao crescimento das plantas-controle. Fatores ambientais provavelmente influenciaram a efetividade da simbiose de ambos os microrganismos e o crescimento da planta. O fertilizante aumentou o crescimento de S. parahyba. Durante os primeiros 120 dias, as plantas sofreram condições de estresse com períodos de seca e geada; aos 180 dias, as plantas inoculadas com microrganismos e adubadas tiveram maior crescimento quando comparada com o controle. Os inoculantes tiveram importação em função do controle da mortalidade das plantas durante os períodos de estresse, mas não foi observado efeito no crescimento da planta. Também, concluiu-se que o período de plantio deve ser entre novembro e dezembro, para evitar que as plantas com porte pequeno entrem no período de inverno, que é seco e frio.

Palavras-chave: Rhizobium sp.; Glomus; Rhizosphere.

\section{INTRODUCTION}

The drastic losses of original native forests in the Northwest region of Parana state in Southern Brazil occurred along the last century during the process of colonization. From $100 \%$ of forest cover in the $19^{\text {th }}$ century, only $5 \%$ of the Atlantic Forest was remnants and many reforestation projects in degraded areas were carried with native trees (IPARDES, 2010).

Leguminous plants have great potential to restore degraded areas, and in addition increase soil quality and fertility (ALVINO-RAYOL et al., 2011). Schizolobium parahyba (Vell.) S.F. Blake var. parahyba (LEWIS, 2010), commonly known as guapuruvu, is a leguminous with fast grow that is used in a reforestation project (PIETROBOM; OLIVEIRA, 2004; SEREDA et al., 2008; CALLADO; GUIMARÃES, 2010). S. parahyba is a pioneer tree that occurs naturally in Atlantic Forest (LORENZI, 1992) in the states of Bahia, Espírito Santo, Paraná, Rio Grande do Sul, Santa Catarina and São Paulo (CARVALHO, 2005). This is considered an ecologically and economically important species due to its significant wood yield potential (BORTOLETTO JÚNIOR; BELINI, 2002).

The use of growth-promoters microorganism inoculum should be considered as a technological improvement of intensive forest cultivation using Nfixing bacteria and arbuscular mycorrhizal fungi (AMF) to increase wood production (SCHIAVO; MARTINS, 2003; SIVIERO et al., 2008). In the rhizosphere soil there are several species of microorganisms composing the microbial community that act in biogeochemical cycles with an important role on soil fertility and plant growth (ANDRADE, 2004; HERNANDÉZ-ORTEGA et al., 2011).

Revista Árvore, Viçosa-MG, v.39, n.4, p.663-670, 2015
Pioneer leguminous woody plants establish symbiosis with AM fungi, which result in benefit for both, transferring $\mathrm{P}$ for plant and carbohydrates to fungi (ZANGARO et al., 2003). Many bacteria from rhizosphere soil can promote plant growth and named plant growth promoting rhizobacteria (PGPR) (ARTUSOON et al., 2006). In many cases, Rhizobium sp. strains, a symbiotic bacteria, can act as PGPR, mainly in non-nodule formation plant as S. parahyba (SIVIERO et al., 2008). The inoculation of legume plants with PGPR and AM fungi can increase plant growth (ABDALLA et al., 2000; MARIN et al., 2010), and there are several reports that show a beneficial effects in the interaction of AMF and diazotrophic bacteria (BAREA et al., 2005; RAIMAM et al.,2007; SALA et al., 2007; MIYAUCHI et al., 2008). The aim of this work was to evaluate the contribution of the microbial inoculants Glomus clarum and Rhizobium sp. in promote plant growth of $S$. parahyba under field conditions.

\section{MATERIALAND METHODS}

\subsection{Experimental Design}

The experiment was carried out at Xambrê, PR,

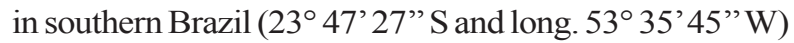
from March to November 2011. The climate is humid subtropical, the mean of rainfall around $1.4 \mathrm{~m}$ year $^{-1}$ (IAPAR, 2000) and the soil was a Rhodic Ferralsol (FAOUNESCO, 1989). The study area (120 $\mathrm{m}$ X $60 \mathrm{~m})$ previously was covered with Brachiaria decumbens and 60 days before planting was sprayed glyphosate to desiccate the grass.

The experimental design was a randomized complete block arranged in a factorial treatment combination with five replications and three factors: $\mathrm{N}$-fixing bacteria 
(Rhizobium sp.), AM fungi (G. clarum) and fertilize NPK (20:5:20), resulting in the following treatments: 1. Control; 2. Rhizobium sp.; 3. G. clarum; 4. Fertilizer; 5. Rhizobium sp. + fertilizer; 6. Rhizobium sp.+ G. clarum; 7. G. clarum + fertilizer; and 8. Rhizobium sp. + G. clarum + fertilizer). Each block was composed by eight plots corresponding to the eight treatments and each plot had twenty plants arranged in spacemen of $3 \mathrm{~m} \mathrm{X} 3 \mathrm{~m}$.

\subsection{Soil and plant}

Soil chemical characterization was made from a composite sample collected before experiment installation at $0-20$ cmof depth. The chemical soil analysis was: $\mathrm{pH}\left(\mathrm{CaCl}_{2}\right) 4.5 ; \mathrm{Al}^{3+} 0.26 \mathrm{cmol}_{\mathrm{c}} \mathrm{dm}^{-3} ; \mathrm{H}+\mathrm{Al} 4.60 \mathrm{cmol}_{\mathrm{c}}$ $\mathrm{dm}^{-3} ; \mathrm{Ca}^{2+} 0.86 \mathrm{cmol}_{\mathrm{c}} \mathrm{dm}^{-3} ; \mathrm{Mg}^{2+} 0.35 \mathrm{cmol}_{\mathrm{c}} \mathrm{dm}^{-3} ; \mathrm{K}^{+}$ $0.26 \mathrm{cmol}_{\mathrm{c}} \mathrm{dm}^{-3}$; P $24.0 \mathrm{mg} \mathrm{dm}^{-3}$; C $7.37 \mathrm{~g} \mathrm{dm}^{-3}$. Seeds of $S$. parahyba were collected at the campus of the State University of Londrina, Londrina, PR, Brazil, selected, mechanically scarified and sown in tubettes in substrate Rhodic Ferralsol (FAO-UNESCO, 1989) mixed with vermiculite $4: 1$. After 30 days, the seedlings were taken to the experimental area and planted.

\subsection{Bacteria inoculum}

The bacterial strain used as inoculum was Rhizobium sp. isolated from nodules of Cassia sp. provided by our own collection. To prepare the inocula, the strain was cultivated in Petri dishes with YMAmedia (VINCENT, 1970) plus Congo red (0.25\%) and incubated at $28^{\circ} \mathrm{C}$ $48 \mathrm{hE}^{1}$. The cells were suspended in sterile saline solution $(\mathrm{NaCl} 0.85 \%)$ at $10^{7}$ colony forming unit (CFU mL $\left.\mathrm{E}^{\prime}\right)$ according to $\mathrm{CaCO}_{3}$ solution standard and $1 \mathrm{~mL}$ of bacterial suspension was dropped around the seedling when the first pair of leaves appeared.

\subsection{AM Fungi inoculum}

The inoculum of G. clarum was from our own collection and is keeping in pots with Brachiaria decumbens. Ten grams of crude inocula (spores, colonized root and mycelia) containing 53 spores $\mathrm{g}^{-1}$ of soil was added in the tubettes, after inoculation a thin layer of soil was covered (around $2 \mathrm{~cm}$ ) and then the seed was sowed. The number of AMF spores and root colonization of $B$. decumbens which was present in the experimental area before the establishment of the experiment was determined and the number of spores and root colonization of S. parahyba were evaluated at the end of experiment. Treatment with chemical fertilization occurred with addition of $100 \mathrm{~g}$ of NPK fertilizer 20-5-20 per plant. The percentage of plants roots infected with AM fungi was estimated on stained samples (PHILLIPS; HAYMAN, 1970) by the grid-line intersect method (GIOVANETTI; MOSSE, 1980) by microscopic examination.

\subsection{Data analysis}

The variables evaluated were total height and survival at 30, 60, 120,180 and 240 days, and stem diameter (10 $\mathrm{cm}$ above the soil) at 180 and 240 days after planting seedlings. Data sets were tested for normality and homogeneity of variance and were evaluated by analyses of variance (ANOVA). The Tukey's Honest significant difference test was performed at $p \mathrm{~d}$ " 0.05 .

\section{RESULTS}

After 30 days no significative differences were observed in the variables analyzed. After 60 days and during the all experiment the plants treated with fertilizer showed higher height when compared with others treatments (Table 1).

The same results were observed in stem diameter (10 cm above the soil) after 180 and 240 days, plants treated with fertilizer showed larger stem diameter when compared with others treatments (Table 2).

Plants survival showed different response. After 30 to 120 days the survival of control plants was the same of more effective treatments, except for Rhi. After 120 days, all treatments showed differences when compared with control except for Rhi and Gc. The survival of control plant was very low after 240 days (16.7\%) and plants inoculated with Rhizobium sp. and G. clarum presented 40 and $36.7 \%$ of plants survival, respectively. However, the treatment Fert showed $73.3 \%$ of survival, but differences were observed only for control, Rhi and Gc. In 180 and 240 days, the dual inoculation (Gc + Rhi) showed good response of survival against stress conditions (around 50\%) as well as when the microorganisms were combined with chemical fertilizer as Rhizobium sp. and G. clarum with 50 to $60 \%$ of survival (Figure1).

During the experiment before 120 days the plants suffered a high stress conditions, first at all there was drought time for 60 days. After 120 days, in June occurred a frost for two days, in this conditions the tropical woody plant suffered an intensive stress with low temperature (Table 3 ).

Revista Árvore, Viçosa-MG, v.39, n.4, p.663-670, 2015 
Table 1 - Total height (cm) of Schizolobium parahyba pv. parahyba treated with AM fungi (Glomus clarum), PGPR Rhizobium sp., and fertilizer NPK 20-5-20 at 30, 60, 120, 180 and 240 days after seedling planting. (Gc) Glomus clarum; (Rhi) Rhizobium sp.; and (Fert) Fertilizer. Means in the column with the same letter are not significantly different according to Tukey test $(p<0.05)$.

Tabela 1 - Altura total $(\mathrm{cm})$ do Schizolobium parahyba var. parahyba tratada com fungo MA (Glomusclarum), PGPR Rhizobium sp. e fertilizante NPK 20-5-20 aos 30, 60, 120, 180 e 240 dias após o plantio das mudas. (Gc) Glomusclarum; (Rhi)Rhizobium sp.; e (Fert) Fertilizante. Médias nas colunas com a mesma letra não apresentam diferenças significativas pelo teste de Tukey $(p<0,05)$.

\begin{tabular}{|c|c|c|c|c|c|}
\hline Treatment & 30 days & 60 days & 120 days & 180 days & 240 days \\
\hline Gc & $23.94 \mathrm{a}$ & $31.15 \mathrm{a}$ & $37.32 \mathrm{a}$ & $44.51 \mathrm{a}$ & $78.73 \mathrm{a}$ \\
\hline Gc control & $25.21 \mathrm{a}$ & $32.79 \mathrm{a}$ & $39.03 \mathrm{a}$ & $46.04 \mathrm{a}$ & $75.99 \mathrm{a}$ \\
\hline Rhi & $24.20 \mathrm{a}$ & $32.05 \mathrm{a}$ & $38.21 \mathrm{a}$ & $42.94 \mathrm{a}$ & $75.27 \mathrm{a}$ \\
\hline Rhi control & $24.96 \mathrm{a}$ & $31.89 \mathrm{a}$ & $38.14 \mathrm{a}$ & $47.61 \mathrm{a}$ & $80.01 \mathrm{a}$ \\
\hline Fertilizer & $24.78 \mathrm{a}$ & $33.97 \mathrm{~b}$ & $41.82 \mathrm{~b}$ & $50.06 \mathrm{~b}$ & $84.60 \mathrm{~b}$ \\
\hline Fert. control & $24.38 \mathrm{a}$ & $29.97 \mathrm{a}$ & $34.53 \mathrm{a}$ & $39.51 \mathrm{a}$ & $68.65 \mathrm{a}$ \\
\hline \multicolumn{6}{|c|}{ ANOVA ( $p$ values) } \\
\hline Gc & 0.0567 & 0.1183 & 0.1986 & 0.8616 & 0.3166 \\
\hline Rhi & 0.2442 & 0.8804 & 0.9605 & 0.2159 & 0.5997 \\
\hline Fertilizer & 0.5363 & 0.0005 & 0.0001 & 0.0053 & 0.0049 \\
\hline Gc*Rhi & 0.5465 & 0.5201 & 0.9303 & 0.6658 & 0.8595 \\
\hline Gc*Fert. & 0.6758 & 0.6316 & 0.9061 & 0.4208 & 0.1484 \\
\hline Rhi*Fert. & 0.2098 & 0.3429 & 0.0825 & 0.1650 & 0.5934 \\
\hline Gc*Rhi*Fert. & 0.6758 & 0.5078 & 0.2063 & 0.7645 & 0.8865 \\
\hline
\end{tabular}

Table 2 - Stem diameter of Schizolobium parahyba pv. parahyba after 180 and 240 days after seedling planting. (Gc) Glomus clarum; (Rhi) Rhizobium sp.; and (Fert) Fertilizer. Means in the column with the same letter are not significantly different according to Tukey test $(p<0.05)$.

Tabela 2 - Diâmetro do caule de Schizolobium parahyba var. parahyba após 180 e 240 dias após o plantio das mudas. (Gc) Glomus clarum; (Rhi) Rhizobium sp.; e (Fert) Fertilizante. Médias nas colunas com a mesma letra não apresentam diferenças significativas pelo teste de Tukey $(p<0,05)$.

\begin{tabular}{lcc}
\hline Treatment & 180 days & 240 days \\
\hline Gc & $1.22 \mathrm{a}$ & $2.27 \mathrm{a}$ \\
Gc control & $1.18 \mathrm{a}$ & $2.30 \mathrm{a}$ \\
Rhi & $1.16 \mathrm{a}$ & $2.18 \mathrm{a}$ \\
Rhi control & $1.24 \mathrm{a}$ & $2.40 \mathrm{a}$ \\
Fertilizer & $1.38 \mathrm{~b}$ & $2.60 \mathrm{~b}$ \\
Fert. Control & $1.00 \mathrm{a}$ & $1.90 \mathrm{a}$ \\
ANOVA ( $p$ values) & & \\
Gc & 0.5537 & 0.7631 \\
Rhi & 0.4850 & 0.3496 \\
Fertilizer & 0.0005 & 0.0011 \\
Gc*Rhi & 0.6919 & 0.6312 \\
Gc*Fert. & 0.8392 & 0.2757 \\
Rhi*Fert. & 0.3367 & 0.9691 \\
Gc*Rhi*Fert. & 0.6351 & 0.7519 \\
\hline
\end{tabular}

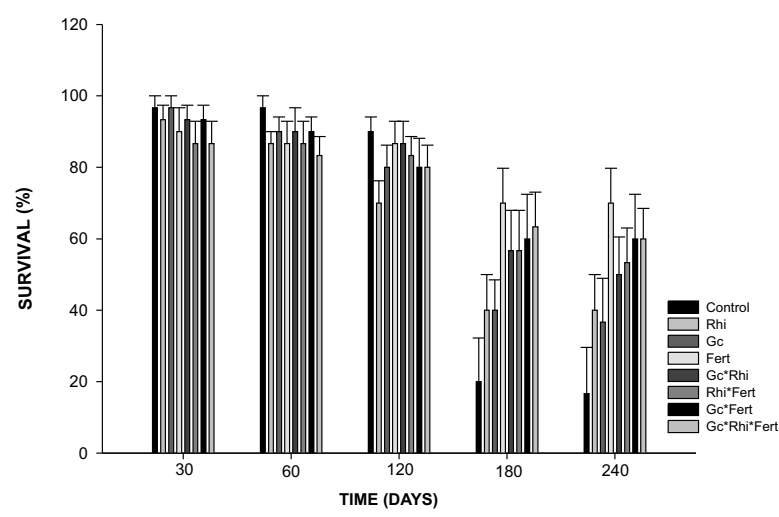

Figure 1-Effect of AM fungi (Glomus clarum), PGPR Rhizobium sp strain, and fertilizer NPK 20-5-20 on survival (\%) on Schizolobium parahyba pv. parahyba at $30,60,120,180$ and 240 days after seedling planting. Bars represent the standard error of mean. Gc: Glomus clarum; Rhi: Rhizobium sp; and Fert.: Fertilizer.

Figura 1 - Efeito do fungo MA (Glomus clarum), da cepa PGPR de Rhizobium sp, e fertilizante NPK 205-20 na sobrevivência (\%) de Schizolobium parahyba var. parahyba, durante $30,60,120$, 180 e 240 dias após o plantio da muda. Barras representam o erro-padrão. Gc: Glomus clarum; Rhi: Rhizobium sp; e Fert.: Fertilizante. 
Table 3-Monthly temperature and pluviometric index during the experimental time (March to November, 2011).

Table 3-Temperatura mensal e índice pluviométrico durante o experimento (março a novembro de 2011).

\begin{tabular}{lccc}
\hline Days & Month & $\begin{array}{c}\text { Temperature } \\
\left({ }^{\circ} \mathrm{C}\right)\end{array}$ & $\begin{array}{c}\text { Precipitation } \\
(\mathrm{m})\end{array}$ \\
\hline Planting & Mar. & 20.5 & 1.031 \\
30 & Apr. & 15.7 & 1.682 \\
60 & May & 14.9 & 0.092 \\
90 & Jun. & 11.0 & 1.389 \\
120 & Jul. & 14.8 & 1.418 \\
150 & Aug. & 15.1 & 1.081 \\
180 & Sep. & 16.4 & 0.692 \\
210 & Oct. & 18.4 & 192.0 \\
240 & Nov. & 19.1 & 205.4 \\
\hline
\end{tabular}

In the soil samples collected before establishment were found 28 spores $\mathrm{g}^{-1}$ of rhizosphere soil, and root samples of B. decumbens showed $83 \%$ of AM root colonization. At the end of the experiment were found 28 spores of AM fungi g-1 of rhizosphere soil from inoculated plants of $S$. parahyba and roots showed $50 \%$ of AM colonization, in non-inoculated plants were found 19 spores $\mathrm{g}^{-1}$ of soil and $30 \%$ of AM root colonization.

\section{DISCUSSION}

Plants from Brachiaria genus are largely used as AMF host, because grass as $B$. brizantha increase the potential of AM inocula in the soil due to its high level of colonization by AM fungi (SANTOS et al., 2000; CAPRONI et al., 2003; CORDEIRO et al., 2005; MELLO et al., 2006). The roots from $B$. decumbens showed high level of AM colonization before $S$. parahyba was planted in the experimental area.

The colonization rate of Brachiaria roots by native AM present in the experimental area did not influence the colonization root of S. parahyba by G. clarum, because the non-inoculated plants showed very low AM colonization when compared with inoculated plant with G. clarum. Is large known that our own inoculum of G. clarum showed high infectivity and effectivity on plant host. The performance of introduced AMF depends of many factors to compete with native AMF such as fast infectivity and establishment and ability to maintain root colonization (WILSON; TOMMERUP, 1992).
On the other hand, Siviero et al. (2008) found that S. parahyba pv. amazonicum inoculated with G. clarum increased plant growth in Amazon area, and agree with Santos et al. (2000) where G. clarum showed high level of root colonization of Cryptomeria japonicum and success to compete with indigenous community of AM fungi.

The low effectiveness of G. clarum on plant growth probably was influenced by high level of $\mathrm{P}$ of soil (24.0 $\mathrm{mg} \mathrm{dm}^{-3}$ ). Is large known that the high concentration P may influence negatively the AM fungi (BRESSAN; VASCONCELLOS, 2002; KIRIACHEK et al., 2009), also Costa et al. (2005) found that the inoculation of AMF in seedlings of Ancornia speciosa and Malpighia ermaginata increases plant growth only in soil with low $\mathrm{P}$ around 3.0 and $4.0 \mathrm{mg} \mathrm{dm}^{-3}$.

G. clarum prefer $\mathrm{pH}$ up to 6.0 (SIQUEIRA; FRANCO, 1988), and the low $\mathrm{pH} 4.5$ in the experimental soil may also influenced the establishment of the symbiosis between G. clarum and plant root. Also the interaction between Rhizobium sp. strain under field conditions is influenced by temperature, soil acidity, nutrient concentration and plant host. These factors can promote low response of inoculation, decreasing efficiency of plant to establish a symbiotic relationship with diazotrophic bacteria (MORAES et al., 2010). In spite of Schizolobium spp is non-nodule forming plant Siviero et al. (2008) found response of Rhizobium sp inoculation acting as free living bacteria in the rhizosphere of $S$. parahyba pv amazonicum.

The presence of G. clarum and Rhizobium sp. did not promote $S$. parahyba growth but protected against stress conditions occurred during the experiment time. After planting the seedlings suffered with dry weeks and a freeze conditions for two days. The non-inoculated plants showed a high level of mortality when compared with inoculated plants with microorganisms or fertilized. Some studies demonstrated that S. parahyba did not support low temperatures and high decrease plant growth or death (CARVALHO, 2003; SOUZA et al., 2011). S. parahyba showed sensibility for temperature variation (CALLADO; GUIMARÃES, 2010) and low capacity of osmotic adaptation when compared with S. parahyba pv amazonicum during water stress (CARVALHO, 2005).

The high mortality observed in non-inoculated plants suggested that low temperatures affected endogenous mycorrhizal symbiosis (HEINEMEYER;

Revista Árvore, Viçosa-MG, v.39, n.4, p.663-670, 2015 
FITTER, 2004), but not inoloculated AM fungi who might increase the tolerance of plants to drought keeping water potential gradient in the root protecting against oxidative stress increasing plant tolerance to drought (PORCEL; RUIZ-LOZANO, 2004). The effects of arbuscular mycorrhizal symbiosis on host plant tolerance against the water deficit caused by drought is related with the increase of stomatal conductance that consequently enhances the water use efficiency of plants (RUIZ-LOZANO; AROCA, 2010).

S. parahyba var. parahyba responded by chemical fertilize increased plant growth but not survival when compared with inoculated plants with G. clarum and/ or Rhizobium sp. suggest that inoculation of microorganisms conferred climate stress resistance. The mortality occurred between 120 and 180 days especially in control plants, the results suggested that the nutrient deficiency associated with environmental factors caused plant stress and death.

\section{CONCLUSIONS}

The high level of $\mathrm{P}$ soil in the experimental area probably decreased the effectiveness of G. clarum and Rhizobium sp. on plant growth when compared with fertilized plants. Also the environmental conditions during winter time (dry season and freeze) increased plant mortality especially of control plants. Otherwise AM fungi and Rhizobium sp. protected plants against drought and freeze. Otherwise, the planting time must be between November to December to avoid the presence of young plants during winter time.

\section{ACKNOWLEDGEMENT}

Thanks to Coordenação de Aperfeiçoamento de Pessoal de Nível Superior (CAPES) for scholarship and $\mathrm{CNPq}$ for grant of research productivity. We also thank to the Agronomic Institute of Paraná State (IAPAR) for grating the experimental area.

\section{REFERENCES}

ABD-ALLA, M.H.; OMAR, S.A.; KARANXHA, S. The impact of pesticides on arbuscular mycorrhizal and nitrogen-ûxing symbioses in legumes. Applied Soil Ecology, v.14, n.1, p.191-200, 2000.

ALVINO-RAYOL, F.O.; ROSA, L.S.; RAYOL, B.P. Effect of spacing and of the use of cover legumes in the management of weed in Schizolobium

Revista Árvore, Viçosa-MG, v.39, n.4, p.663-670, 2015 amazonicum Huber ex. Ducke plantation. Revista Árvore, v.35, n.3, p.391-399, 2011.

ANDRADE, G. Role of functional groups of microorganisms on the rhizosphere microcosm dynamics. In: VARMA, A.; ABBOTT, L.; WERNE, D.; HAMPP, R. (Ed). Plant surface microbiology. New York: Springer-Verlag, 2004. p.51-68.

ARTUSOON, V.; FINLAY, R.D.; JANSSON, J.K. Interactions between arbuscular mycorrhizal fungi and bacteria and their potential for stimulating plant growth. Environment Microbiology, v.8, n.1, p.1-10, 2006.

BAREA, J.M.; POZO, M.J.; AZCÓN, R.; AZCÓNAGUILAR, C. Microbial co-operation in the rhizosphere. Journal Experimental Botany, v.56, n.417, p.1761-1778, 2005.

BORTTOLETO JÚNIOR, G.; BELINI, U.L. Produção de lâminas e manufatura de compensados a partir da madeira de guapuruvú (Schizolobium parahyba ) proveniente de um plantio misto de espécies nativas. Cerne, v. 8, n.2, p.1-16, 2002.

BRESSAN, W.; VASCONCELLOS, C.A. Morphological alterations on root system of maize induced by mycorrhizal fungi and phosphorus. Pesquisa Agropecuária Brasileira, v.37, n.4, p.509-517, 2002.

CALLADO, C.H.; GUIMARÃES, R.C. Tree-ring study of Schizolobium parahyba (Leguminosae: Caesalpinioideae) after a mortality episode in Ilha Grande, Rio de Janeiro state. Revista

Brasileira de Botânica, v.33, n.1, p.85-91, 2010.

CAPRONI, A.L.; FRANCO, A.A.; BERBARA, R.L.L.; TRUFEM, S.B.; GRANHA, J.R.D.O.; MONTEIRO, A.B. Arbuscular mycorrhizal fungi occurrence in revegetated areas after bauxite mining at Porto Trombetas, Pará State, Brazil. Pesquisa Agropecuária Brasileira, v.38, n.12, p. 1409-1418, 2003.

CARVALHO, C.J.R. Responses of Schizolobium amazonicum (S. parahyba var. amazonicum) and Schizolobium parahyba (Schizolobium parahybum) plants to water stress. Revista Árvore, v.29, n.6, p.907-914, 2005. 
CARVALHO, P.E.R. Brazilian tree species. Brasília: Embrapa Technological Information, 2003.

CARVALHO P.E.R. Guapuruvu. Colombo: Embrapa Technological Information, 2005. 10p.

CORDEIRO, M.A.S.; CARNEIRO, M.A.C.; PAULINO, H.B.; SAGGIN-JUNIOR, O.J. Colonization and spore density of arbuscular mycorrhizal fungi in two cerrado soils in different tillage systems. Pesquisa Agropecuária Tropical, v.35, n.1, p.147-153, 2005.

COSTA, C.M.C.; CAVALCANTE, U.M.T.; GOTO, B.T.; SANTOS, V.F.; MAIA, L.C. Arbuscular mycorrhizal fungi and phosphorus supply on seedlings of mangabeira. Pesquisa Agropecuária Brasileira, v.40, n.3, p.225-232, 2005.

FAO-UNESCO/ISRIC 1998. Soil map of the world. Revised Legend. Rome: World Soil Resources, 1998. (Report, 60).

GIOVANETTI, M.; MOSSE, B. An evaluation of techniques for measuring vesicular-arbuscular micorrhizal infections in roots. New

Phytologist, v. 84, n.3, p.489-500, 1980.

HEINEMEYER, A.; FITTER, A.H. Impact of temperature on the arbuscular mycorrhizal (AM) symbiosis: growth responses of the host plant and its AM fungal partner. Journal Experimental Bototany, v. 55, n.395, p.525-534, 2004.

HERNÁNDEZ-ORTEGA, H.A.; ALARCÓN, A.; FERRERA-CERRATO, R.; ZAVALETA-

MANCERA, H.A.; LÓPEZ-DELGADO, H.A.; MENDOZA-LÓPEZ, M.R. Arbuscular mycorrhizal fungi on growth, nutrient status, and total antioxidant activity of Melilotus albus during phytoremediation of a diesel-contaminated substrate. Journal Environment Managment, v.95, p.319-324, 2011.

IAPAR. Cartas climáticas do Estado do Paraná. 2000. Available at: http://www.iapar.br/ modules/conteudo/conteudo.php?conteudo $=677$. Accessed 3 Dec 2012.

IPARDES. Environmental indicators for river basins of the State of Paraná. Curitiba: 2010. (Technical Note Ipardes)
KIRIACHEK, S.G.; AZEVEDO, L.C.B.; PERES, L.E.P.; LAMBAIS, M.R. Regulation of arbuscular mycorrhizae development. Revista Brasileira Ciência do Solo, v.33, n.1, p.1-16, 2009.

LEWIS, G.P. Schizolobium in List of Species of Flora from Brazil (Schizolobium in Lista de Espécies da Flora do Brasil). Botanical Garden of Rio de Janeiro. 2010. Available at: http:// floradobrasil.jbrj.gov.br/2010/FB023142. Accessed 25 Nov 2012.

LORENZI, H. Árvores brasileiras: manual de identificação e cultivo de plantas arbóreas nativas do Brasil. Nova Odessa: Platarum, 1992. 352p.

MARIN, M.; MENA, J.; FRANCO, R.; PIMENTEL, E.; SÁNCHEZ, I. Effects of the bacterial-fungal interaction between Tsukamurella paurometabola C 924 and Glomus fasciculatum and Glomus clarum fungi on lettuce microrrhizal colonization and foliar weight. Biotecnología Aplicada, v.27, n.1, p.48-51, 2010.

MELLO, A.H.; ANTONIOLLI, Z.I.; KAMINSKI, J.; SOUZA, E.L.; OLIVEIRA, V.L. Arbuscular and ectomycorrizal fungi in eucalypt cultivation and grassland sandy soil. Ciência Florestal, v.16, n.3, p.293-301, 2006.

MIYAUCHI, M.Y.H.; LIMA, D.S.; NOGUEIRA, M.A.; LOVATO, G.M.; MURATE, L.S.; CRUZ, M.F.; FERREIRA, J.M.; ZANGARO, W.; ANDRADE, G. Interactions between diazotrophic bacteria and mycorrhizal fungus in maize genotypes. Science Agriculture, v.65, p.525-531, 2008.

MORAES, W.B.; MARTINS FILHO, S.; GARCIA, G.O.; CAETANO, O.S.; MORAES, W.B.; COSMI, F.C. Evaluation of biological fixation of nitrogen in Rhizobium sp under water deficit. Idesia, v.28, n.1, p.61-68, 2010.

PHILLIPS, D.A.; HAYMAN, D.S. Improved procedures for clearing roots and staining parasitic and vesicular-arbuscular mycorrhizal fungi for rapid assessment of infection. Transaction British Mycology Society, v.55, n.1, p.158-161, 1970.

PIETROBOM, R.C.V.; OLIVEIRA, D.M.T. Morphology, anatomy and development of Schizolobium parahyba (Vell.) Blake (Fabaceae,

Revista Árvore, Viçosa-MG, v.39, n.4, p.663-670, 2015 
Caesalpinioideae) pericarp. Revista

Brasileira Botânica, v.27, n.4, p.767-779, 2004.

PORCEL, R.; RUIZ-LOZANO, J.M. Arbuscular mycorrhizal influence on leaf water potential, solute accumulation, and oxidative stress in soybean plants subjected to drought stress.

Journal Experimental Botany, v.55, n.403, p.1743-1750, 2004.

RAIMAM, M.P.; ALBINO, U.; CRUZ, M.F.; LOVATO, G.M.; SPAGO, F.; FERRACIN, T.P.; LIMA, D.S.; GOULART, T.; BERNARDI, C.M.; MIYAUCHI, M.; NOGUEIRA, M.A.; ANDRADE, G. Interaction among free-living $\mathrm{N}$-ûxing bacteria isolated from Drosera villosa var. villosa and AM fungi (Glomus clarum) in rice (Oryza sativa). Applied Soil Ecology, v.35, n.1, p.25-34, 2007.

RUIZ-LOZANO, J.M.; AROCA, R. Host response to osmotic stresses: stomatal behaviour and water use efficiency of arbuscular mycorrhizal plants. In: KOLTAI, H.; KAPULNIK, Y. Arbuscular mycorrhizas: physiology and function. New York: Springer, 2010. p.239-254.

SALA, V.M.R.; FREITAS, S.S.; SILVEIRA, A.P.D. Interaction between arbuscular mycorrhizal fungi and diazotrophic bacteria in wheat plants. Pesquisa Agropecuária Brasileira, v.42, n.11, p.15931600, 2007.

SANTOS, A.L.; DE-SOUZA, F.A.; BERBARA, R.L.L.; GUERRA, J.G.M. Establishment and infective capacity of Gigaspora margarita Becker \& Hall and Glomus clarum Nicol. \& Gerd. in eroded soil. Acta Botanica Brasileira, v. 14, n.2, p.127-139, 2000.

SCHIAVO, J.; MARTINS, M.A. Production of Acacia plants colonized with mycorrhizas and rhizobium in different recipients. Pesquisa
Agropecuaria Brasileira, v.38, n.2, p.173$178,2003$.

SEREDA, F.; REISSMANN, C.B.; MARQUES, R.; BRITEZ, R.M. Nutritional aspects of seeds and plantule of guapuruvu developed in two substrates. Scientia Agraria, v.9, p.575-579, 2008.

SIQUEIRA, J.O.; FRANCO, A.A. Soil

Biotechnology: fundamentals and prospects. Brasília: MEC/ABEAS, 1988. 235p.

SIVIERO, M.A.; MOTTA, A.M.; LIMA, D.S.; BIROLLI, R.R.; HUH, S.Y.; SANTINONI, I.A.; MURATE, L.S.; CASTRO, C.M.A.; MIYAUCHI, M.Y.H.; ZANGARO, W.; NOGUEIRA, M.A.; ANDRADE, G. Interaction among N-ûxing bacteria and AM fungi in Amazonian legume tree (Schizolobium amazonicum) in ûeld conditions. Applied Soil Ecology, v.39, n.1, p.144-152, 2008.

SOUZA, V.Q.; CARON, B.O.; SCHMIDT, D.; BEHLING, A.; BAMBERG, R.; VIAN, A.L. Resistance of arboreal species submitted to extreme frost in different agroforestry systems. Ciência Rural, v.41, n.6, p.972-977, 2011.

VINCENT, J.M. A manual for the practical study of root-nodules bacteria. Oxford : Brackwell Science Publication, 1970.

WILSON, J.M.; TOMMERUP, I.C. Interactions between fungal symbionts: VA mycorrhizae. In: ALLEN, M.F. (Ed.). Mycorrhizal functioning. London: Chapman and Hall, 1992. p.199-248.

ZANGARO, W.; NISIZAKI, S.M.A.; DOMINGOS, J.C.B.; NAKANO, E.M. Mycorrhizal response and successional status in 80 woody species from south Brazil. Journal Tropical Ecology, v.19, n.2, p.315-324, 2003. 